\title{
Artikel
}

\section{Beheersing van legaal particulier (vuur)wapenbezit: de voorgeschiedenis}

\author{
Mr. J.H. Maat MSSM*
}

\section{Vrees voor misbruik}

'Ik vraag mij ook af, "Waarom moeten mensen een wapen hebben?" Volgens mij is de staat de enige die monopolie heeft op geweld, en de politie natuurlijk, maar daarbuiten zou ik zeggen, gewoon streng toezien dat mensen geen wapens hebben. ${ }^{1}$ Dit was de reactie van Tweede Kamervoorzitter Arib naar aanleiding van ophef over de mogelijke registratie van etniciteit en religie van houders van een vuurwapenverlof of jachtakte in $2018 .^{2}$

Deze reactie is exemplarisch voor het uitgangspunt in de Nederlandse wapenwetgeving, dat is gericht op de beheersing van het legale en de bestrijding van het illegale wapenbezit. ${ }^{3}$ Dat beleid kan succesvol worden genoemd als wordt gekeken naar de resultaten van het onderzoek dat de Europese Commissie in 2013 heeft laten uitvoeren naar vuurwapenbezit binnen de Europese Unie: van de ondervraagden in Nederland geeft $95 \%$ aan geen vuurwapen te bezitten en dit ook

* Mr. J.H. Maat MSSM is buitenpromovendus aan de Radboud Universiteit en doet onderzoek naar risicobeheersing van legaal particulier vuurwapenbezit in Nederland in historisch perspectief. Hij is gespecialiseerd in risicobeheersing binnen de domeinen veiligheid, integriteit en crisisbeheersing en is werkzaam bij de Rijksoverheid. Met dank aan prof. mr. H.J.B. Sackers van de Radboud Universiteit voor zijn commentaar op de conceptversie van dit artikel.

1. 'Goedemorgen Nederland' (WNL, NPO), 27 september 2018 , 8:13-8:14, npostart.nl/goedemorgen-nederland/27-09-2018/POW 03914754

2. Handelingen // 2018/19, nr. 52, item 31 (vergadering van 12 februari 2019).

3. Kamerstukken I/ 1994/95, 24107, nr. 3, p. 1. nooit te hebben gehad. Dit is het hoogste percentage binnen de Europese Unie. Hierna komen het Verenigd Koninkrijk met 94\% en Malta met 93\%. De landen met de laagste percentages zijn Kroatië met $83 \%$, Finland met $83 \%$ en Cyprus met $68 \%$. Het EU-gemiddelde is $90 \%{ }^{4}$ Vergeleken met de Verenigde Staten is het contrast ook groot, daar heeft $70 \%$ van de ondervraagden geen vuurwapen in bezit. ${ }^{5}$ In Nederland is het legale particuliere vuurwapenbezit geregeld in de Wet wapens en munitie (WWM) en de Wet natuurbescherming (Wnb). Het bezit van vuurwapens is aan particulieren alleen toegestaan indien er sprake is van een 'redelijk belang' (artikel 28, tweede lid, WWM), zoals het beoefenen van de schietsport of een wapen- of munitieverzameling. Zelfverdediging is tegenwoordig slechts in zeer uitzonderlijke gevallen een redelijk belang. ${ }^{6}$ Om de jacht te

4. Firearms in the European Union, Flash Eurobarometer 383, European Commission, oktober 2013, p. 7. Van de ondervraagden in het onderzoek gaf $1 \%$ aan op dat moment een vuurwapen te bezitten en $4 \%$ in het verleden (bijlage van het rapport, p. T11). De (voormalig) wapenbezitters gaven de volgende grondslagen op: $11 \%$ jacht, $42 \%$ sport, $3 \%$ verzamelen, $44 \%$ beroepsmatig (niet nader gespecificeerd), $5 \%$ zelfverdediging en $10 \%$ overig (bijlage van het rapport, p. T13-14), hierbij is overigens niet gevraagd of het wapen legaal of illegaal in bezit is/was.

5. K. Parker, J. Horowitz, R. Igielnik, B. Oliphant \& A. Brown, America's Complex Relationship With Guns: An In-depth Look at the Attitudes and Experiences of U.S. Adults, Washington DC: Pew Research Center 2017, p. 16. De vraagstelling wijkt overigens iets af van het onderzoek binnen de Europese Unie. Zo is niet gevraagd naar het voormalig vuurwapenbezit. Van de ondervraagden gaf $30 \%$ aan zelf een vuurwapen in bezit te hebben en $11 \%$ gaf aan dat een huisgenoot een vuurwapen in bezit had. Zie ook A. Karp, Estimating global civilian-held firearms numbers, Briefing Paper June 2018, Geneva: Small Arms Survey 2018, p. 5, over de problematiek van het correct schatten/meten van legaal en illegaal vuurwapenbezit in het kader van het Small Arms Survey.

6. In 2018 ging het bijvoorbeeld om twaalf verloven ter zelfverdediging, zoals bescherming van expedities in gevaarlijke (pool)gebieden. Daarnaast werden acht verloven afgegeven ter bescherming tegen piraterij in risicogebieden, Politie, Besluit Wob-verzoek wapenverloven (nr. 5857), 11 juni 2019 (overzicht 2018). 
mogen uitoefenen met een vuurwapen dient men over een jachtakte te beschikken, wat is geregeld in de artikelen 3.27 en 3.28, tweede lid, Wnb. ${ }^{7}$ Circa 60.000 particulieren zijn op basis van de WWM en de Wnb gerechtigd een vuurwapen voorhanden te hebben. ${ }^{8}$ De korpschef van de Nationale Politie en de staatssecretaris van Justitie en Veiligheid zijn verantwoordelijk voor het vergunningstelsel, waaronder het toezicht op en de handhaving van het legale particuliere vuurwapenbezit.

Centraal hierin staat de 'vrees voor misbruik'. Indien hiervan sprake is zal de wapenvergunning worden geweigerd of ingetrokken. Het gaat dan bijvoorbeeld om (strafrechtelijk) contact met politie en justitie, en/of rechterlijke veroordelingen wegens misdrijven of overtredingen. Maar ook een geldboete - opgelegd bij strafbeschikking of transactie - valt hieronder, net zoals een proces-verbaal of mutatierapport dat (nog) niet tot een vervolgingsbeslissing of veroordeling heeft geleid, ook als deze geen betrekking hebben op wapens. Uiteraard wordt hierbij wel een terugkijktermijn gehanteerd en worden de aard en de ernst van de gedraging meegewogen. Verder is de psychische gesteldheid van de aanvrager of houder van belang om te bepalen of een vuurwapen aan de houder kan worden toevertrouwd en het bezit geen gevaar voor zichzelf, de openbare orde of veiligheid kan vormen. Tot slot is het naleven van de vergunningsvoorschriften van belang. Voor een houder van een jachtakte geldt bijvoorbeeld de eis dat deze 'niet nalatig is te doen wat een goed jager betaamt bij de uitoefening van de jacht' (artikel 5.4, zesde lid, onderdeel b, Wnb). Voor elke vergunninghouder geldt dat deze zijn vuurwapen(s) en munitie op de voorgeschreven wijze dient te vervoeren en op te bergen. Hiertoe krijgen de verlofhouders en jachtaktehouders periodiek en op een onverwacht moment thuis controle van de politie. ${ }^{9}$

De WWM is een hybride wet die zowel het legale als illegale wapenbezit reguleert. De juridische sfeerovergang kan plotseling zijn. Wordt de vergunning om een van bovengenoemde redenen ingetrokken, dan is het direct niet meer toegestaan om handelingen met het wapen te verrichten, waaronder het voorhanden hebben. Ook het niet tijdig verlengen van een vergunning maakt vanaf de dag dat deze is verlopen van de legale een illegale wapenbezitter. ${ }^{10}$ De achterliggende gedachte van deze strengheid wordt in de Circulaire wapens en munitie treffend omschreven: er mogen geen twijfels zijn 'over de aanvaardbaarheid van de uitzonderingspositie waarin de aanvrager (vergunninghouder) komt te verkeren (verkeert) ten opzichte van zijn medeburgers. Daarbij moet wel worden bedacht dat betrokkene zoveel mogelijk de gelegenheid moet krijgen zich te verweren

7. De legale productie, reparatie en handel van wapens wordt hier verder buiten beschouwing gelaten.

8. Politie, Besluit Wob-verzoek wapenverloven (nr. 5857), 11 juni 2019 (overzicht 2018)

9. H.J.B. Sackers, Wet wapens en munitie, Deventer: Wolters Kluwer 2020, p. 468-479; Paragraaf 9.1, Circulaire wapens en munitie, Stcrt. 2020, 5669.

10. Sackers 2020 , p. 147 tegen de tegen hem bestaande bedenkingen.' ${ }^{11}$ Een flinke verkeersovertreding, onjuist ingevulde belastingaangifte of burenruzie kan al aanleiding zijn het wapenverlof of de jachtakte in te trekken. ${ }^{12}$ Een legaal particulier vuurwapenbezitter moet dus welhaast een modelburger zijn.

Duidelijk mag zijn dat 'vrees voor misbruik' een belangrijk begrip in de wapenwetgeving is. Het kent een lange historie, onder meer in de voorlopers van de WWM, namelijk de 'Wet van 9 mei 1890 houdende verbodsbepalingen tegen het dragen van wapenen' (kortweg: Wapenwet 1890) en de Vuurwapenwet 1919, waarin het particuliere vuurwapenbezit de afgelopen 130 jaar steeds meer aan banden werd gelegd. ${ }^{13}$ Opmerkelijk genoeg was de beheersing van particulier vuurwapenbezit historisch gezien niet altijd restrictief van aard. In dit artikel wordt ingegaan op de voorgeschiedenis van de risicobeheersing van legaal particulier (vuur)wapenbezit in Nederland, gedurende de late middeleeuwen tot het begin van de Republiek in de tweede helft van de zestiende eeuw. ${ }^{14}$

\section{Weerplicht: heervaart en landweer}

$\mathrm{Al}$ in de vroege middeleeuwen bestond het beginsel dat elk vrij man bereid moest zijn de eigen gemeenschap of het eigen land te verdedigen. Het luiden van de klok, slaan van de trom of blazen van de hoorn was een teken dat men het werk moest laten liggen en zich moest verzamelen om het naderende onheil te lijf te gaan. ${ }^{15}$ Deze weerplicht gold zowel in de stad als op het platteland. Het ging dan om gezonde mannen tussen de zestien (of achttien) en zestig jaar oud, waarbij er wel regionale verschillen waren in hoeverre armen ('paupers'), zeevarenden en gewetensbezwaarden waren uitgezonderd. Daarnaast waren er weduwen die als gezinshoofd geen weerplicht, maar wel wapens hadden. Hiermee kon een fysiek sterk familielid voor deze taak worden uitgerust. ${ }^{16}$ Men was georganiseerd naar landsgemeente, parochie, wijk of gilde en stond onder leiding van zelfgekozen rechters en bestuurders. ${ }^{17}$ Dit beginsel heeft lang doorgewerkt in wet- en regelgeving. Een voorbeeld hiervan uit de late middeleeuwen (1270-1500) is het Landrecht

11. Circulaire wapens en munitie, Stcrt. 2020, 5669, p. 31

12. Sackers 2020, p. 471

13. J.H. Maat, 'Uit vrees voor de "Kladderadatsch", Vuurwapenbezit aan banden gelegd', Historisch Nieuwsblad, december 2019, p. 59-64.

14. Legaal particulier wapenbezit ten behoeve van de jacht speelt buiten de bezitters van dit 'heerlijke recht' geen rol in deze periode en wordt verder buiten beschouwing gelaten. Vuurwapens komen voor de jacht pas in de zeventiende eeuw in beeld: R.T.W. Kempers, Antieke vuurwapens, Bussum: Unieboek 1977, p. 197.

15. J.H. Mol, De Friese volkslegers tussen 1480 en 1560. Met een editie van de Monsterlijsten van Friesland 1552 en Ameland 1558 door P.L.G. van der Meer en J.H. Mol, Hilversum: Verloren 2017, p. 14.

16. Mol 2017, p. 70-71

17. Mol 2017, p. 11-12. 
van Drenthe uit 1412. De landsheer van Drenthe, de Utrechtse bisschop Frederik van Blankenheim, codificeerde hiermee het Drentse gewoonterecht. In het Landrecht werden het strafrecht en strafprocesrecht, de rechterlijke organisatie (met name de Etstoel), de bisschoppelijke belastingheffing en - in artikel 1 - het algemene keurrecht geregeld. Dit laatste gaf de inwoners op elk niveau (buurschap, kerspel, dingspel, landschap) het recht te vergaderen en besluiten te nemen. Daarom wordt het Landrecht ook wel de 'Drentse grondwet' genoemd. Deze relatieve autonomie schiep via artikel 40 Landrecht echter ook de verplichting tot gewapende bijstand tot elkaar. In geval van oorlog of gevaar moesten alle weerbare mannen - of de meest daartoe geschikte man uit het huishouden - gewapend opkomen om het land te verdedigen of criminelen (zoals moordenaars, brandstichters of rovers) te vervolgen of te verjagen. ${ }^{18}$ In Westerlauwers Friesland (vergelijkbaar met het huidige Friesland) - waar sprake was van een communale autonomie - was oorlogvoering tot het midden van de vijftiende eeuw zelfs een voornamelijk burgerlijke aangelegenheid: 'de Friese vrijheid kon alleen floreren als de dragers ervan bereid waren haar met hun lijf en goed te beschermen.' ${ }^{19}$ Uit noodzaak, maar ook uit eer. Zo was het krijgerschap een belangrijk onderdeel van de middeleeuwse Friese cultuur, zelfs al was niet elke Vrije Fries een krijger. ${ }^{20}$

Deze weerplicht - een vorm van volksbewapening - was tweeledig en bestond uit de heervaart en de landweer. De heervaart had een offensief karakter: men ging letterlijk na oproep van de landsheer - zoals de bisschop, graaf of hertog - met een leger ('heer', in het Duits is dit nog steeds de benaming voor de landmacht) op veldtocht om de vijand op te zoeken. Dat waren niet noodzakelijkerwijs grote militaire expedities naar verre oorden of veldslagen. Het ging vooral om kortdurende expedities in de eigen regio, bestaande uit plundering en vernieling van de economische capaciteit van de tegenstander. In 1471 en 1480 werd bijvoorbeeld een groot deel van de weerbare mannen van Zutphen door de hertog van Gelre opgeroepen voor een heervaart naar Grave en Nijmegen. ${ }^{21}$ In Holland beschermden 174 gewapende gezellen op 19 januari 1492 de timmerlieden en smidsknechten die door de stadsbesturen van Gouda en Dordrecht op pad waren gestuurd om de 'verlaten' (schutsluizen) - zoals in de Hildam bij Benthuizen - te vernielen die een alternatieve vaarroute creëerden ten behoeve van bijvoorbeeld Rotterdam en Leiden en hiermee de tol- en handelsrechten van Gouda en Dordrecht zouden schaden. ${ }^{22}$ Bij de landweer was juist sprake van een defensie-

18. C.L. Rahder, Eenige aanteekeningen op het Landrecht voor Drenthe van 1412 (diss. Utrecht), Amsterdam, C.A. Spin \& Zoon, 1879 p. $85-87$.

19. Mol 2017, p. 12.

20. J.A. Nijdam, Lichaam, eer en recht in middeleeuws Friesland: een studie naar de Oudfriese boeteregisters (diss. Leiden), Hilversum: Verloren 2008 , p. 300

21. Mol 2017, p. $16-18$

22. J.C. Smit, 'De strijd om de binnenvaart door Midden-Holland in de vijftiende en de zestiende eeuw', Tidinge van die Goude, 1994-1, p. 21. ve situatie waarbij de vijandelijke inval of een overval van bandieten moest worden afgeweerd.

Om aan deze weerplicht gehoor te kunnen geven, werd men geacht wapens te bezitten en te kunnen hanteren. ${ }^{23}$ Vanaf de tweede helft van de vijftiende eeuw treedt met name voor de heervaart een verschuiving op naar de inzet van de beter getrainde huursoldaten - zoals piekeniers uit Zwitserland en landsknechten uit Zuid-Duitsland - die werden betaald uit de belastingen die de landsheer aan de bevolking oplegde. ${ }^{24}$ De landweer bleef echter langer van kracht. Dat voor de landweer niet op huursoldaten werd vertrouwd was niet voor niets. Huursoldaten vochten louter voor het geld en werden niet betrouwbaar geacht, los van het risico dat ze bij gebrek aan betaling of opdrachtgever als sprinkhanen op plundertocht zouden gaan. Huursoldaten hadden ook een ander 'ethos'. Waar bijvoorbeeld de Vrije Friezen gevangen edellieden tegen losgeld weer vrijlieten, werden deze door de huursoldaten soms zonder pardon afgeslacht. ${ }^{25}$ Het idee van volksbewapening is onder andere beschreven door de Florentijn Niccolò Machiavelli. Zo stelt hij in zijn Il Principe in 1513: 'Wanneer men hier opwerpt dat ieder die over wapens beschikt dit [het ten gronde richten van de heerser, JHM] zal doen, of hij nu huursoldaat is of niet, dan antwoord ik dat de wapens ofwel gehanteerd moeten worden door de heerser alleen ofwel door het volk in zijn totaliteit. [...] En de ondervinding leert dat alleenheersers en gewapende volksmachten zeer grote successen behalen, terwijl huurlegers alleen maar schade aanrichten. [...] Ook de Zwitsers, die tot de tanden gewapend zijn, verheugen zich in een zeer grote vrijheid.' ${ }^{26}$ Bewapende burgers hadden immers een eigenbelang, ze beschermden hun bezit en familie, dit in tegenstelling tot de huursoldaten. Ook de landsheer zou hier voordeel van hebben: 'Want als je het volk bewapent, kun je over die gewapende macht beschikken.' ${ }^{27}$ Bovendien leverde het loyaliteit op, want het schonk vertrouwen. ${ }^{28}$ Zes jaar later stelt hij in Discorsi: 'Ik geloof dat je het volgende onderscheid moet maken: óf de bevolking van je land is weerbaar, zoals de Romeinen of tegenwoordig de Zwitsers, óf ze is dat niet, zoals de Carthagers en tegenwoordig de onderdanen van de koning van Frankrijk en de Italianen. ${ }^{29}$

In de veertiende eeuw kregen in het zuidelijke deel van de Nederlanden (en andere delen van Noord-Europa) de gilden een dominantere rol in de stadsbesturen, mede door hun toenemende rol in de stadsverdediging. De

23. Mol 2017, p. 14.

24. Mol 2017, p. 11, 15.

25. Nijdam 2008, p. 20, 113.

26. N. Machiavelli, De heerser, Amsterdam: Athenaeum - Polak \& Van Gennep 1976 (II principe 1513, vertaald door F. van Dooren), p. 102-103.

27. Machiavelli (1513) 1976, p. 138

28. M. Prak, Citizens without Nations. Urban Citizenship in Europe and the World. C. 1000-1789, Cambridge: Cambridge University Press 2018, p. 143.

29. N. Machiavelli, Discorsi. Gedachten over staat en politiek, Amsterdam: Ambo/Anthos 1997 (Discorsi sopra la prima deca di Tito Livio 1519, vertaald door P. van Heck), II.12-18, p. 304 
Guldensporenslag van 1302 - waarbij een Frans leger van bereden ridders werd vernietigd door een voetleger van Vlaamse ambachtslieden - wordt hierin wel als startpunt gezien. ${ }^{30}$ De steden kregen ook politiek een sterkere positie doordat zij beter in staat waren zich te organiseren ten opzichte van de edelen, die meestal slechts enkele 'ruters' - gewapende knechten - in dienst hadden. ${ }^{31}$ Knevel typeert de vroegmoderne steden als een gemeenschap van wapenbroeders, met eigen semimilitaire organisaties die verantwoordelijk waren voor rust en orde en in tijden van nood de stad moesten helpen verdedigen. ${ }^{32}$ Naast de algemene weerplicht bestonden er ook schutterijen in de steden. De leden moesten het burgerrecht van de stad hebben, dus 'poorter' zijn, in een Amsterdamse schuttersbrief omschreven als een 'goede poorter'. Hiermee werd gerefereerd aan de materiële welstand, want de schutter moest zijn wapenrusting in beginsel zelf bekostigen. ${ }^{33}$ De schutters verrichtten schietoefeningen - eerst met hand- en kruisboog, later met vuurwapens - en waren verantwoordelijk voor het 'beschutten', het handhaven van de openbare orde (de stadsvrede). In de meeste Hollandse steden was dit per wijk georganiseerd, in veel Vlaamse steden per ambacht. ${ }^{34}$

\section{Monsterlijsten}

Naast de wapens die van overheidswege werden aangeschaft, ${ }^{35}$ moesten de burgers ter vervulling van deze weerplicht dus vaak zelf in wapens voorzien. ${ }^{36}$ Dat blijkt bijvoorbeeld uit de ordonnantie van 9 januari 1450 van de stad Leiden ten aanzien van de leden van het schuttersgilde: 'elc tot sijnen live hebben sal, hem selve toe behoorende, een goet pansijser, een ijserhoet [et cetera]. ${ }^{37}$ Omdat wapens kostbaar konden zijn, was dit in bepaalde gevallen gekoppeld aan de welstand. Zo kende men in Westerlauwers Friesland op basis van het Oude Schoutenrecht in de twaalfde eeuw in de artikelen 82 en 84 een vierdeling in 'schijven' naar gelang de waarde van het onroerend goed dat men in bezit had: tot 12 pond: handboog; 12-20 pond: speer en schild; 20-30 pond: zwaard; 30 pond en meer: paard met wapen. ${ }^{38}$ In Leiden kende men in 1477 een verdeling in vijf schijven. ${ }^{39}$ Ook

30. Prak 2018, p. 186-187.

31. Nijdam 2008, p. 112.

32. P. Knevel, Burgers in het geweer, Schutterijen in Holland 1550-1700, Hilversum: Verloren 1994, p. 13.

33. Knevel 1994, p. 35

34. Knevel 1994, p. 47.

35. F.H.W. Kuypers, Het oudste vuurgeschut in Nederland (overdruk uit: Militaire Spectator 1862 , p. 647-659, 724-737; 1863, p. 17-28), z.p.: z.u., 1863, p. 20-24, 34

36. Hiermee wordt gedoeld op zaken die specifiek voor de strijd waren bedoeld, dus niet de werktuigen (zoals zeisen en dorsvlegels) of messen en dolken die iedereen destijds bij zich droeg voor de dagelijkse bezigheden, maar ook ter zelfverdediging.

37. Kuypers 1863, p. 26.

38. W.J. Buma \& W. Ebel (m.m.v. M. Tragter-Schubert), Westerlauwerssches Recht, 1. Jus municipale frisonum, Göttingen 1977.

39. Knevel 1994, p. 48. uit Drenthe is een verdeling van verplicht wapenbezit naar welstand bekend op basis van een oordeel (uitspraak) van de Etstoel van Rolde uit 1399, waarbij onderscheid werd gemaakt tussen de rijkere eigengeërfde boeren en de armere pachters. Op het niet nakomen van deze bepalingen inzake wapenbezit stonden boetes. $^{40}$

Mede doordat Karel V als landsheer behoefte had aan een overzicht van de inzetbaarheid van weerbare mannen werd het wapenbezit per huishouden - inclusief het verzuim hierin - keurig bijgehouden in zogenoemde 'monsterlijsten'. ${ }^{41}$ Zoals boedelbeschrijvingen inzicht geven in de algemene welstand en de bezittingen van burgers in een bepaalde periode, ${ }^{42}$ zo geven deze wapenschouwen die de tand des tijds hebben doorstaan een accuraat overzicht van het particuliere wapenbezit, waaronder vuurwapens. Hoewel vuurwapens al in de veertiende eeuw in de Nederlanden in gebruik werden genomen, ${ }^{43}$ werden deze pas algemener - zeker voor particulieren - en hanteerbaarder in de vijftiende en zestiende eeuw. Het gaat dan met name om de haak of haakbus (een primitief handvuurwapen dat met een haak op een verschansing kon steunen) en de roer (voorloper van het musketgeweer). Deze vuurwapens waren relatief eenvoudig en goedkoop door een plaatselijke wapensmid te vervaardigen en het gebruik vergde weinig training, zeker vergeleken met de handboog en kruisboog. ${ }^{44}$ Haakbussen waren ook goedkoper dan kruisbogen, vandaar dat in de decennia na 1510 de hand- en kruisbogen bijna overal werden ingewisseld voor de haakbussen en roeren. ${ }^{45}$ Deze toename blijkt ook uit de monsterlijsten. Zo rapporteert Haring van Sythiema, de grietman (een soort plattelandsburgemeester) van Ferwerderadeel, op de monsterlijst voor zijn landsheer Karel V van 20 januari 1552 dat 43 van de 603 'den ingesetenen zijnre grietenien, eedel ende oneedel' in het bezit zijn van een roer en vier van een halve haak. ${ }^{46}$ Schijnbaar niet zonder trots vermeldt de steller van de monsterlijst ook zijn eigen bezit, zijnde een 'vlanckaert, stormhoedt, hellebaerde, dubbelde haeck ende andere haecken met meer diverse gheweer'. ${ }^{47} \mathrm{De}$ meeste ingezetenen beschikten overigens alleen over slag-, steek- en stokwapens en een kleine honderd gezinshoofden waren in het geheel niet in het bezit van wapens. ${ }^{48}$ Uit de belangrijke inventarisatie van Mol en Van der Meer blijkt dat de verhouding particulier vuurwapenbezit niet zozeer door welstand wordt bepaald, maar meer door de verhouding platteland (circa 12\%)

40. Mol 2017, p. 43

41. Mol 2017, p. 24.

42. H. Dibbits, 'Families en hun spullen: boedelbeschrijvingen als bron', in: P. Stokvis (red.), Geschiedenis van het privéleven. Bronnen en benaderingen, Amsterdam/Heerlen: SUN/Open Universiteit 2007, p. 263-264.

43. Kuypers 1863, p. 4-6.

44. Kempers, 'Haakbussen uit Nederlands bezit', Armamentaria, 1976, p. $75-97$.

45. Knevel 1994, p. 93.

46. Een halve, hele en dubbele haak zijn aanduidingen van kalibers.

47. Gheweer/geweer was destijds een verzamelterm voor wapens, het gaat dus niet specifiek om vuurwapens.

48. Mol 2017, p. 212-221. 
en stad (circa 20\%). ${ }^{49}$ Interessant is overigens dat uit de monsterlijsten van het Overijsselse Hasselt en Alkmaar blijkt dat men vaak meerdere wapens per persoon had, namelijk een wapen voor de lange(re) afstand zoals een vuurwapen, hellebaard of spies, en een korter wapen zoals een degen voor het nabije gevecht. De knots gold hierbij als het 'lowbudget-wapen', de drager hiervan had niets anders. Maar er waren ook rijke patriciërs met een uitgebreid privéarsenaal in huis zoals de Alkmaarse rentmeester Dirck Sijmonszoon die beschikte over twee hellebaarden, twee gavelijnen, twee roeren, een slagzwaard, twee rapieren, twee bogen en een 'outscutterij geweer' (waarschijnlijk een vuurwapen). ${ }^{50}$

Dat de weerplicht voortkwam uit een reële dreiging blijkt uit de inventarisatie van 25 maart 1558 van Peter van Cammingha, de vrijheer van Ameland. Hij schreef een uitgebreide toelichting over de dreiging die zeerovers vormen voor de bevolking. Deze bandieten, bijvoorbeeld uit Hamburg en Schotland, voeren dagelijks langs het eiland en de vrees bestond dat ze 's avonds aan land zouden gaan om de bewoners van het bed te lichten en te beroven. Daarom had de vrijheer met zijn edelen besloten het wapenbezit onder de bevolking actief te bevorderen en ook wapens te verstrekken: 'ende dat vermits gebreecke van geweer, dat zelven wij gedencken ende willen vorhoeden voer soe veele ons mogelicken sal sijn, ende soe guede getrouwe heren vor hoiren ondersaeten behoiren te doen'. Deze distributie was niet vrijblijvend, op verlies van het wapen stond een gouden gulden boete, bij recidive het dubbele. Deze aansporing van overheidswege verklaarde dan ook het relatief grote aantal vuurwapens op het eiland. De 392 huishoudens van Ameland telden 102 halve haken en 12 roeren, 29\% van de huishoudens was dus in het bezit van vuurwapens. De rest beschikte over slag-, steek- en stokwapens. ${ }^{51}$ Opmerkelijk is dat het legale particuliere vuurwapenbezit op Ameland nog steeds relatief hoog is. Uit een Wob-verzoek in 2019 bij de politie is gebleken dat Ameland omgerekend 683 vuurwapens per tienduizend inwoners heeft, dat is het hoogste in Nederland, het gemiddelde in Nederland is $114 .^{52}$

Net als tegenwoordig werden ook vroeger van overheidswege voorschriften uitgevaardigd inzake het bewaren van wapens. Deze zijn soms bewaard gebleven, juist vanwege de heterogeniteit van het recht in de Nederlanden. Karel V vaardigde in 1531 namelijk een edict uit dat de geldende rechten ter plekke - de 'stedelijke costumen' - op schrift moesten worden gesteld en vervolgens ter goedkeuring (homologatie) naar Brussel

49. Mol 2017, p. 81-82

50. Mol 2017, p. 96-97

51. M.A.P. Robijn-Voorn, 'Amelanders bewapend tegen zeerovers', De Amelander, 2019-02 (maart/april), p. 16-17; Mol 2017, p. 81, 329-336.

52. J. Vermanen \& T. van Bree, 'Legaal wapenbezit op laagste punt in 12 jaar', pointer.kro-ncrv.nl/artikelen/legaal-wapenbezit-op-laagste-puntin-12-jaar, 5 juni 2019. Gelet op het inwonertal van Ameland (januari 2019: 3.673) is er natuurlijk wel sprake van enige vertekening. worden gestuurd. ${ }^{53}$ Het stadsrecht van Leeuwarden werd zo in een 'Stadtsboeck' vastgelegd, waarin artikel 25 bepaalde dat de burgers die hiertoe door het stadsbestuur waren aangewezen hun harnas en wapens gereed moesten houden en niet uit mochten lenen: 'Item, alle de gene, die op harnasch to holden geset ende ordineert wordden vanden gheenen, die daer vanden Raet verordent zint, die zullen altyt hoere harnasch ende geweer feerdich hebben ende daermede, oftet noot zij, anden festen haestelijcken gereet zijn. Oick moet nyemant harnasch off enige geweer vuytleenen, dat hy selffs daerbij gebreck hebbe. Ende soe vaecken die Raet off yemant anders vandes Raets wegen schouwinge gebieden toe holden, daertoe een ygelijcke mit zijn harnasch ende geweer feerdich toe zijn, bij pena een halff olde schildt.' Via artikel 83 Leeuwarder Stadsrecht waren deze zaken ook gevrijwaard van het beslagrecht, net als het gereedschap van ambachtslieden waarmee zij de kost moesten verdienen, een bepaling die nog voortleeft in artikel 447 Rv. ${ }^{54}$ Opmerkelijk is overigens dat die homologatie, die een bedreiging was voor de lokale privileges in de Noordelijke Nederlanden, heeft bijgedragen aan het ongenoegen dat leidde tot de Opstand in 1568 in de Nederlanden tegen de landsheer Philips II. ${ }^{55}$ Hierbij zijn onvermijdelijk ook wapens ingezet die eerder in opdracht van zijn vader, de vorige landsheer Karel V, zijn geïnventariseerd.

\section{Wapeninghe}

Bij gebrek aan een staand leger of een politiemacht waren bewapende burgers noodzakelijk voor de veiligheid van de gemeenschap, bovendien was wapenbezit noodzakelijk voor individuele zelfbescherming, zowel van lijf en goed als de eer. ${ }^{56}$ Maar, aan de andere kant was er de vrees voor misbruik, zowel gericht op andere burgers als tegen het (hogere) gezag. Een risico dat zich af en toe ook manifesteerde, ook voor de Opstand in de Nederlanden van 1568 .

Dit ondervond de Bourgondische hertog Filips de Goede toen deze hoge belastingen had ingevoerd en de burgers van Gent tot een mapeninghe kwamen, wat resulteerde in een gewapende opstand. ${ }^{57}$ Deze Gentse Opstand (1449-1453) werd op 23 juli 1453 neergeslagen

53. J.H.A. Lokin \& W.J. Zwalve, Hoofdstukken uit de Europese Codificatiegeschiedenis, Groningen: Wolters-Noordhoff 1992, p. 244.

54. A. Telting, De Friesche Stadrechten, Leeuwarden: 1883, ontsloten via: https://historischcentrumleeuwarden.nl/stad/stadsgeschiedenis/ stadsrecht.

55. Lokin \& Zwalve 1992, p. 245.

56. Nijdam 2008, p. 54, 283, 287

57. Een wapening is een vorm van collectieve actie ter verdediging van de verworven rechten van de ambachten (gilden) en vond gefaseerd plaats. Het begon met het gewapend bijeenkomen in de neringhuizen (gildehuizen) om druk uit te oefenen en kon uiteindelijk uitmonden in daadwerkelijke militaire actie zoals gebeurde met de Gentse Opstand; J. Haemers, De Gentse opstand (1449-1453), De strijd tussen rivaliserende netwerken om het stedelijk kapitaal, Kortrijk-Heule: UGA 2004, p. 195-205. 
in de Slag bij Gavere, waarbij de hertog kon profiteren van paniek die ontstond toen een Gentse kanonnier een lont bij het kruitval liet vallen. Een paar weken later, op 13 augustus 1453, vaardigde Filips de Goede een bevel uit waarin algemene ontwapening van alle burgers van Gent en de overige bewoners van steden en dorpen in Vlaanderen werd bevolen. ${ }^{58}$ Dit was overigens niet voor het eerst, want ook na de neergeslagen opstand van 1379-1385 was al eens een verbod ingesteld op het bezit van en het oefenen met wapens door boeren en burgers. In 1459 volgde een uitgebreide ordonnantie van de hertog. Artikel 16 luidde: 'Niemanden, dan die syn van de justitie, ofte de selven assisteren, mogen gaen bij daghe, noch bij nachte in gewijde, ofte ongewijde plaetsen, binnen de steden, noch ten platten lande, met eenighe booghen, handt- , voet-, ofte armbogen, Pijcken, Calven met tacken, Glizernen, Bremessen, Houweren, Goudsen, Herhameren, Palskeren binnen met ijzer, langhe Messen, langhe Daggen, 't zijnde in de snede langer als twee voeten. ${ }^{59}$ Opmerkelijk is dat vuurwapens nog niet in deze opsomming worden genoemd, kennelijk waren vuurwapens in deze periode nog te exclusief voor particulier bezit, dit in tegenstelling tot het beeld dat ontstaat door de monsterlijsten van krap een eeuw later. Interessant is ook dat de eerste drie zinsdelen doorwerken tot in de huidige WWM. De verbodsbepalingen van de artikelen 9, 13, 14, 22, 26 en 27 zijn conform artikel 3a WWM niet van toepassing bij de functievervulling van personen die deel uitmaken van of werkzaam zijn voor de krijgsmacht, politie en overige openbare diensten voor zover dit bij regeling is bepaald. Dit betekent overigens niet dat een dergelijke functionaris in de particuliere hoedanigheid vrij is in het bezit (en dragen) van een vuurwapen. ${ }^{60}$ De bepaling van Filips de Goede bleef lang van kracht in opeenvolgende wetten, waaronder in delen van Nederland. Opgemerkt dient te worden dat de beperking vooral betrekking had op het dragen van wapens. Het bezit werd niet verder beperkt. Minister van Justitie Ruijs de Beerenbrouck haalde deze vroege voorloper van de Wapenwet van 1890 bij de behandeling in de Tweede Kamer dan ook aan als onderbouwing dat de beperking van het dragen van wapens door burgers al van vroeger tijden was. Dit was een reactie op de stelling van het sociaaldemocratische Kamerlid Domela Nieuwenhuis dat de Wapenwet 1890 in feite een gelegenheidswet - een socialistenwet - was, de minister had immers zelf aangegeven dat hij de wet 'in de tegenwoor-

58. V. Fris, Nieuwe oorkonden betreffende den opstand van Gent tegen Philips den Goede, Gent: Geirnaert-Vandesteene 1906, p. 210.

59. Ord. Philippi Boni, 14 augustus 1459, zoals genoemd in: A. Anselmo, Codex Belgicus seu ius edictale a principibus Belgarum sancitum: Ofte de nederlandtsche, nieuwe soo gheestelycke, als wereltlycke rechten, ghetrocken uyt de vier placcaetboecken tot Gendt ende Antwerpen uytghegeven, Antwerpen: Petrus Bellerus 1662, p. 263.

60. Een militair die als lid van een burgerschietvereniging een pistool wil bezitten voor het beoefenen van de schietsport heeft hiervoor een verlof nodig, net zoals een politieagent die een geweer wil hebben voor de jacht over een jachtakte moet beschikken. dige tijdsomstandigheden noodig' achtte, waarbij hij inderdaad doelde op de socialistische manifestaties. ${ }^{61}$

Het handhaven van een wapenverbod was in de praktijk lastig. Zo mochten de Kennemers en West-Friezen in Holland na de Kennemeropstand van 1426 van de Bourgondische hertog 'geen wapene, harnasch of weere' in hun huizen hebben en alleen nog maar 'broitmessen sunder punte' dragen. ${ }^{62}$ Toch kwam het zelden tot daadwerkelijke effectuering van het verbod, enerzijds omdat er geen efficiënt politieapparaat bestond dat hierop kon handhaven en anderzijds omdat men zowel in de steden als in de rurale gebieden nu eenmaal in eerste instantie op zichzelf was aangewezen voor zelfbescherming, onder meer door rondtrekkende en brandschattende huurlingen in de frontgebieden. Zowel in de periode 1488-1494 als 1504-1528 kregen de burgers in Holland wederom de opdracht zich van wapens en wapenrusting te voorzien. Landsheer Filips de Schone riep in 1506 vanwege de weer oplaaiende Gelderse oorlogen de burgers van Holland op zich ter zelfverdediging uit te rusten met bepantsering en een handwapen zoals een piek, vuurwapen, kruisboog of hellebaard. ${ }^{63}$

\section{Beheersing}

In de beschreven periode was wapenbezit in het kader van de weerplicht een algemeen verschijnsel, maar niet ongereglementeerd. Uit het onderzoek van Cox blijkt dat de meeste stadsrechtoorkonden nadere verbods- en boetebepalingen hadden om te voorkomen dat deze wapens te snel binnen de stadsmuren ter hand zouden worden genomen. ${ }^{64}$ Dit wordt geillustreerd in het Leeuwarder stadsrecht dat, zoals hiervoor aangegeven, wapenbezit verplicht stelde en beschermde tegen het beslagrecht. Maar het stadsbestuur legde met artikel 185 wel beperkingen op in de wapendracht: na tien uur 's avonds mocht men niet gewapend de straat op gaan: 'Sal oick nyemant mit eenige geweer oft zonder lanteerne nae thien wren tzauents byde straeten ghaen, by verboernisse van dat gheweer ende peen van een olden schilt, doch altijt nemende acht opte persoonen. ${ }^{95}$ Ook waren er beperkingen om ongewenste wapens tegen te gaan, bijvoorbeeld in lengte en breedte van de kling. De beperkingen golden voor de eigen poorters binnen de stadsmuren, maar ook voor mensen van buiten. Zo moesten inwoners van Walcheren een Middelburgse poorter als geleide hebben om gewapend door Middelburg te mogen trekken. ${ }^{66}$

61. Handelingen I/ 1889-1890, p. 1097-1116, 28-03-1890, Verbodsbepalingen tegen het dragen van wapenen (Wapenwet 1890); Maat, Historisch Nieuwsblad 2019, p. 59-60

62. J.C.W. Cox, 'Hebbende privilege van stede', De verlening van stadsrechtprivileges in Holland en Zeeland (13de-15de eeuw) (diss. Leiden), z.p.: 2011, p. 263.

63. Mol 2017, p. 17-18.

64. Cox 2011, p. 224-226.

65. Telting 1883

66. Cox 2011, p. 224-226. 
Figuur 1 Haakbussen en toepassingen hiervan, uit: F.H.W. Kuypers, Het oudste vuurgeschut in Nederland, Militaire Spectator 1863.

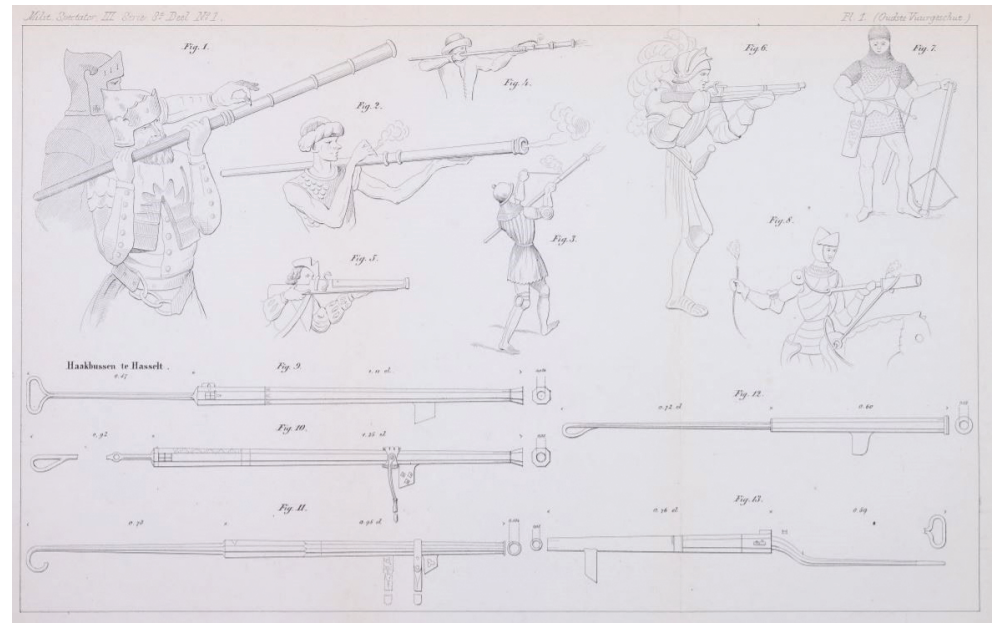

Misbruik van het wapenbezit was verder gewoon strafbaar, zeker als dit leidde tot blijvend letsel of de dood, wat resulteerde in een te betalen compensatie of de doodstraf. ${ }^{67}$ Huisvredebreuk - 'huysbrekinghe ende huysstotinghe', wat op zichzelf al een zwaar misdrijf was - werd nog zwaarder bestraft wanneer hierbij wapens werden gebruikt. De bewoner bleef dan ook meestal ongestraft wanneer deze zich hiertegen verweerde, zelfs in geval van doodslag, deze werd dan geacht uit 'nootwere' te hebben gehandeld. In artikel 12 Grondwet komt het belang van huisvrede terug, al is de bewoner tegenwoordig niet per definitie straffeloos bij verweer. ${ }^{68}$

Zoals uit het voorgaande blijkt, kent de beheersing van overheidswege op particulier wapenbezit in Nederland een lange voorgeschiedenis, die terugvoert tot onder meer het tijdperk van de Vrije Friezen en de Bourgondische en Habsburgse Nederlanden. Men zou kunnen stellen dat de houding ambivalent was, waarbij niet alleen sprake was van beperkingen op particulier wapenbezit. Wapenbezit is van overheidswege zelfs actief bevorderd, waarbij controles aan huis - anders dan tegenwoordig - bedoeld waren om vast te stellen of men wel over voldoende wapens beschikte om de weerplicht als onderdeel van de burgerplicht te kunnen vervullen. Er werden echter wel maatregelen genomen om het risico van misbruik tegen zowel medeburgers als het (hogere) gezag zoveel mogelijk beheersbaar te maken, waarvan sommige nog doorwerken tot heden ten dage. ${ }^{69}$

68. Cox 2011, p. 221-224; dit was het geval bij 31 van de 61 onderzochte Stadsrechtoorkonden.

69. In een volgende bijdrage zal worden ingegaan op de beheersing van legaal particulier (vuur)wapenbezit ten tijde van de Republiek der Zeven Verenigde Nederlanden. 
Figuur 2 Monsterlijst Ameland, 25 maart 1558, p. 2. Bron: Nationaal Archief, Nassause Domeinraad, (1218) 1581-1811 (1842), nummer archiefinventaris 1.08.11, inventarisnummer 1822: 'Ordonnantie van Peter Cammingha, heer van Ameland, betreffende de bemapening van de bevolking van Ameland in verband met zeeroverij om en op Ameland, met lijst van namen en bemapening', 25 maart 1558 (p. 2). Foto: M.A.P. Robijn-Voorn.

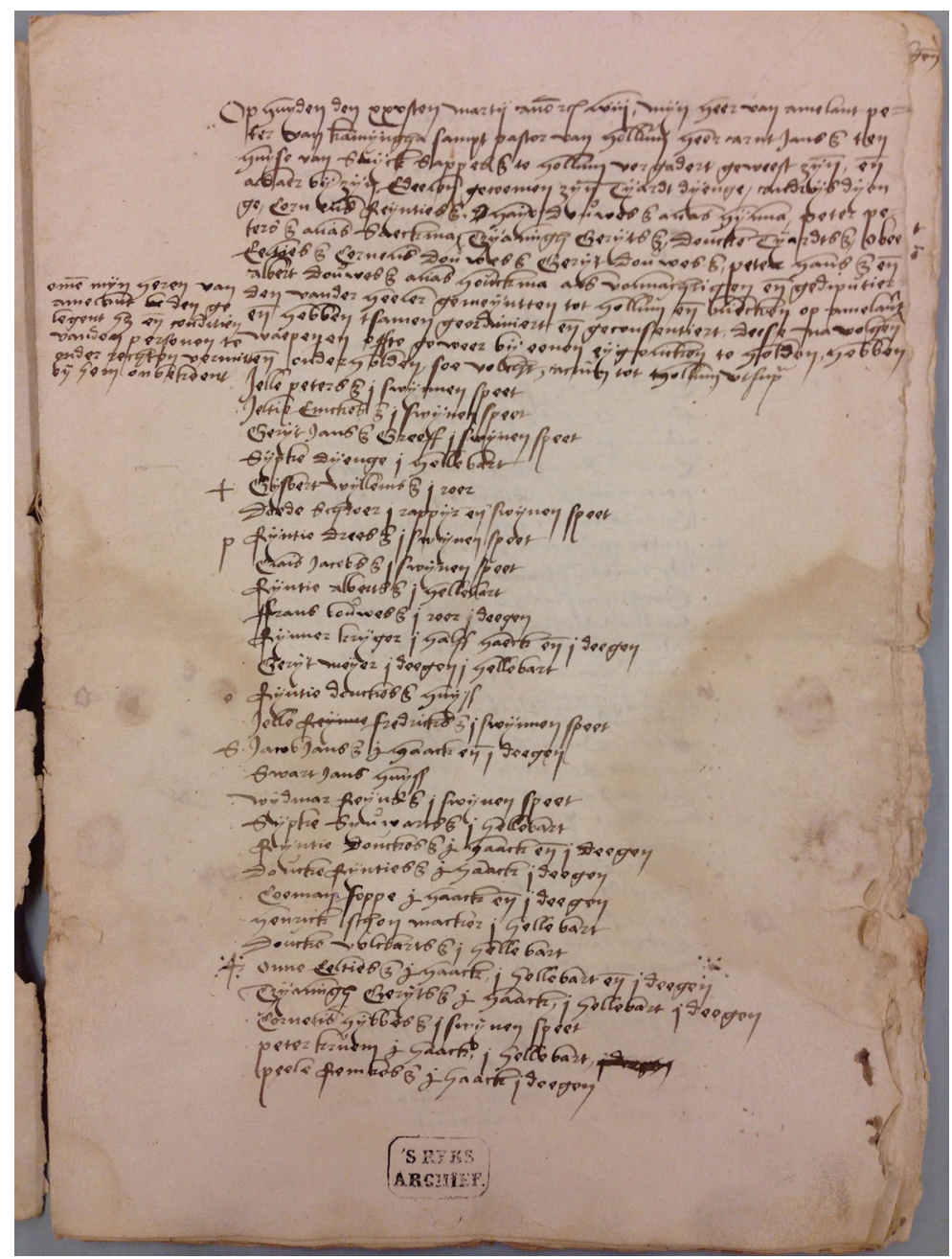

